\title{
Lack of association between CAG repeat polymorphism in the androgen receptor gene and the outcome of rheumatoid arthritis treatment with leflunomide
}

\author{
Violetta Dziedziejko • Mateusz Kurzawski • Krzysztof Safranow • Andrzej Ossowski • \\ Jaroslaw Piatek • Miroslaw Parafiniuk • Dariusz Chlubek • Andrzej Pawlik
}

Received: 15 August 2011 / Accepted: 22 September 2011 /Published online: 14 October 2011

(C) The Author(s) 2011. This article is published with open access at Springerlink.com

\begin{abstract}
Purpose Leflunomide (LEF) is a disease-modifying antirheumatic drug used for treating rheumatoid arthritis (RA) and the action of which may be modified by sex hormones. The aim of this study was to examine the association between CAG repeat polymorphism in the androgen receptor $(A R)$ gene and the response to treatment with LEF in women with RA. Methods We studied 114 women diagnosed with RA and treated with LEF (20 mg daily). Follow-up was 12 months. CAG repeat polymorphism was determined using polymerase chain reaction (PCR) and subsequent fragment analysis by capillary electrophoresis.

Results Analysis revealed no statistically significant associations between CAG repeat polymorphism in the $A R$ gene
\end{abstract}

\footnotetext{
V. Dziedziejko $\cdot$ K. Safranow $\cdot$ D. Chlubek

Department of Biochemistry and Medical Chemistry,

Pomeranian Medical University,

Powstancow Wlkp. 72,

70-111 Szczecin, Poland

M. Kurzawski

Department of Experimental and Clinical Pharmacology,

Pomeranian Medical University,

Powstancow Wlkp. 72,

70-111 Szczecin, Poland

A. Ossowski $\cdot$ J. Piatek $\cdot$ M. Parafiniuk

Department of Forensic Medicine,

Pomeranian Medical University,

Powstancow Wlkp. 72,

70-111 Szczecin, Poland

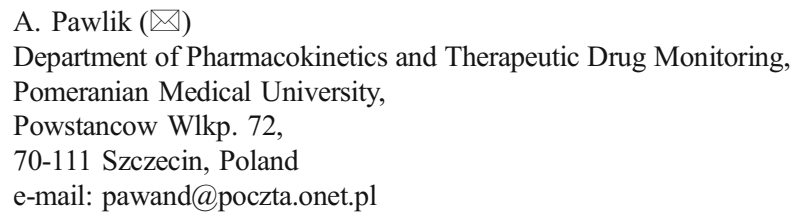

and improvement of disease activity parameters: erythrocyte sedimentation rate, serum C-reactive protein, patient's global assessment of disease activity on a visual analog scale (VAS), disease activity score of 28 joints (DAS28), and swollen and tender joint count.

Conclusion Our results suggest no correlation between CAG repeat polymorphism in the $A R$ gene and response to treatment with LEF in women with RA.

Keywords $(\mathrm{CAG})_{\mathrm{n}}$ repeat polymorphism · Androgen receptor . Leflunomide $\cdot$ Rheumatoid arthritis

\section{Introduction}

Rheumatoid arthritis (RA) is a chronic inflammatory systemic disease that affects the joints and often leads to severe disability. Disease-modifying antirheumatic drugs (DMARDs), such as methotrexate, sulphasalazine, and leflunomide (LEF), can retard joint destruction [1-3]. It has been shown that LEF is effective and well tolerated in the treatment of RA [4]. One mechanism of LEF action in suppressing inflammation is based on its inhibition of dihydroorotate dehydrogenase (DHODH), an enzyme responsible for de novo synthesis of pyrimidine nucleotides. Moreover, polymorphism in the $D H O D H$ gene may be associated with LEF treatment response and toxicity $[5,6]$. Upon absorption, LEF is quickly metabolized to malononitrilamide (MNA or A77 1726) as the active therapeutic agent. MNA selectively inhibits DHODH and, thus, suppresses T-cell proliferation [7]. Via its effect on T cells, LEF addresses several levels of the inflammatory cascade and has antiproliferative, antiinflammatory, and antidestructive abilities $[8,9]$. The antiinflammatory effect is related to its ability to inhibit osteoclastogenesis and production of metal- 
loproteinases and proinflammatory cytokines by activated synovial cells and macrophages $[10,11]$. This special mode of action, together with its rapid onset of action, makes it a promising drug for treating RA, in which preventing irreversible structural damage is an important goal.

Previous studies indicated poorer response to treatment in women than in men $[12,13]$. Possible reasons for gender differences in RA activity could be explained on the basis of sex hormones and their receptors. Sex hormones, acting through their intracellular receptors, play an important role in regulating the immune/inflammatory response in RA [14]. The androgen receptor $(A R)$ gene, present on the $\mathrm{X}$ chromosome, contains a highly polymorphic CAG (glutamine) repeat in the region encoding $\mathrm{NH}_{2}$-terminal transactivation domain, which normally varies between 9 and 37 repeats (approximately 10-30 in Caucasians) $[15,16]$. CAG length $\left[(\mathrm{CAG})_{\mathrm{n}}\right]$ is inversely associated with the $A R$ transcriptional activity such that, having longer $(C A G)_{n}$, it reduces $A R$ transcriptional activity and subsequent intracellular androgenic activity $[16,17]$. Studies have shown that the $A R$ CAG polymorphism is clinically relevant. $(\mathrm{CAG})_{\mathrm{n}}$ longer than about 37 repeats is associated with pathologic conditions related to reduced androgenicity, such as gynecomastia and ineffective spermatogenesis [16]. Shorter $A R$ CAG repeats have been associated with hormone-related cancer risk, such as prostate cancer [18].

In our previous study, we indicated that estrogen receptor gene (ESR1) polymorphisms in women with RA may be associated with response to treatment with LEF [19]. The aim of the study presented here was to examine the association between CAG repeat polymorphism in the androgen receptor gene and response to therapy of women with RA treated with LEF.

\section{Materials and methods}

\section{Patients}

The study was carried out on 114 women, mean age $54.1 \pm$ 11.0 years, diagnosed with RA (disease duration $10.8 \pm$ 7.0 years). Monotherapy of $20 \mathrm{mg}$ /day LEF was used. RA was diagnosed according to criteria of the American College of Rheumatology (ACR). All patients underwent a monthly evaluation for 1 year from initiation of treatment with LEF. The assessed variables included the number of swollen joints, number of tender joints, patient's global assessment of disease activity on a $10-\mathrm{cm}$ visual analog scale (VAS), erythrocyte sedimentation rate (ESR), serum C-reactive protein (CRP), and disease activity score for 28 joints (DAS28) (including metacarpophalangeal joints, proximal interphalangeal joints, wrists, and elbows) [2022]. Written informed consent was obtained from patients according to the Declaration of Helsinki, and the Ethical Committee approved the study design.

\section{Genotyping}

Genomic DNA was extracted from $200 \mu \mathrm{l}$ of whole blood samples with GeneMATRIX Quick Blood DNA Purification Kit (EURx, Poland) and subsequently standarized to $20 \mathrm{ng} / \mu \mathrm{l}$ concentration. The DNA region containing CAG repeats within the $A R$ gene was amplified with a pair of flanking primers: 5'-TCC AGA ATC TGT TCC AGA GCG TGC-3', 5'-ACT GCG GCT GTG AAG GTT GCT GT-3' [23]. Forward primer was fluorescently labeled with 6carboxyfluorescein (6-FAM). Amplification was carried out in $15 \mu \mathrm{l}$ volume using AmpliTaq Gold 360 Master Mix (Applied Biosystems, USA), $0.2 \mu \mathrm{M}$ of each primer, and 1 $\mu \mathrm{l}$ of genomic DNA, in 27-cycle polymerase chain reaction (PCR) (primer annealing temperature $57^{\circ} \mathrm{C}$ ). Length of the amplification product was subsequently analyzed by capillary electrophoresis: $1 \mu \mathrm{l}$ of each sample was mixed with $12 \mu \mathrm{l}$ of Hi-Di Formamide (Applied Biosystems) $+0.5 \mu \mathrm{l}$ of GeneScan 500 LIZ Size Standard and put into an ABI PRISM 3130 Genetic Analyzer with an autosampler module. Electrophoresis was run on 36-cm capillary arrays filled with POP-4 polymer. Data were gathered with Data Collection v.3.0 software and further analyzed with GeneMapper ID-X 1.1 software. A number of CAG repeats corresponding to the length of amplified DNA fragments assessed by capillary electrophoresis was verified by sequencing of randomly chosen homozygous samples using the same primers as described above. PCR product was initially purified using YM-100 centrifugal filters (Microcon, USA) and sent out for sequencing to a commercial service (oligo.pl, Poland).

Statistical analysis

Distributions of disease activity parameters were significantly different from normal ( $p<0.05$, Shapiro-Wilk test) in most cases. Therefore, we used nonparametric tests. The Kruskal-Wallis test was followed by the Mann-Whitney test to compare disease activity parameters and their changes between genotype groups. Spearman rank correlation coefficient (Rs) was calculated to measure correlations between the number of CAG repeats and disease activity parameters. $P<0.05$ was considered statistically significant. We performed power calculation based on standard deviation (SD) of DAS28 improvement (0.8) from our previous study [19] to compare $A R$ genotypes. It revealed that the study reported here, with 114 patients, has statistical power sufficient to detect with $80 \%$ probability the differences of DAS28 improvement between genotype groups equal to 0.6 . 


\section{Results}

The number of $A R$ CAG repeats in the studied group ranged from 11 to 34 (median 22). The frequency distribution of $A R$ genotypes was in Hardy-Weinberg equilibrium $(p=0.80) . A R$ genotypes and alleles were classified according to median. Alleles with $<22 \mathrm{CAG}$ were classified as short $(\mathrm{S})$ and those with $\geq 22 \mathrm{CAG}$ as long (L). The patients studied could thus be divided into three groups: those with two short alleles ( $S-S, n=31)$, those with two long alleles ( $\mathrm{L}-\mathrm{L}, \mathrm{n}=31$ ), and those with one short and one long allele ( $\mathrm{S}-\mathrm{L}, \mathrm{n}=52$ ).

Table 1 presents the associations between disease activity parameters and $A R$ genotypes at onset and after 12 months of treatment with LEF. As shown, there were no statistically significant differences between genotype groups compared with Kruskal-Wallis test. The improvement of disease activity parameters during treatment with LEF in association with $A R$ genotypes is presented in Table 2. These associations were statistically nonsignificant.

We also analyzed the shorter and the longer allele CAG repeats separately. Additionally, for each patient, the mean number of repeats was calculated from the formula (shorter allele CAG repeats + longer allele CAG repeats) $/ 2$. With regard to disease activity parameters in patients stratified according to median CAG repeat length of shorter $A R$ allele (19), longer $A R$ allele (23), and their mean (21.5), there were statistically significant associations with some baseline disease activity parameters (ESR, CRP, VAS); however, there were no associations with the parameters after 12 months of therapy with LEF or with changes in parameters during therapy (Table 3).

We analyzed correlations between RA activity parameters and CAG repeat length of $A R$ alleles at onset and after 12 months of therapy. The only statistically significant associations were negative correlations between the VAS and CAG repeats in longer allele $\left(R_{\mathrm{S}}=-0.25, p=0.006\right)$ and mean of CAG repeats in shorter and longer alleles $\left(R_{\mathrm{s}}=-0.22, p=0.02\right)$. Spearman rank correlation coefficients between changes of RA activity parameters during treatment with LEF and CAG repeat length of $A R$ alleles are shown in Table 4. No significant correlations were found.

Table 1 The association of disease activity parameters with androgen receptor $(A R)$ genotypes at onset and after 12 months of treatment with leflunomide

\begin{tabular}{|c|c|c|c|c|c|c|c|}
\hline \multirow[t]{2}{*}{ Parameters } & \multicolumn{3}{|c|}{$A R$ genotypes $($ mean $\pm \mathrm{SD})$} & \multirow[t]{2}{*}{$P$ value ${ }^{\mathrm{a}}$} & \multicolumn{3}{|l|}{$P$ value $^{\mathrm{b}}$} \\
\hline & S-S & S-L & L-L & & S-S vs L-L & S-S vs S-L $+\mathrm{L}-\mathrm{L}$ & S-S +S-L vs L-L \\
\hline \multicolumn{8}{|l|}{$\operatorname{ESR}(\mathrm{mm} / \mathrm{h})$} \\
\hline At onset & $61.5 \pm 27.5$ & $48.6 \pm 26.9$ & $49.2 \pm 22.6$ & 0.057 & 0.053 & 0.017 & 0.53 \\
\hline After 12 months & $39.0 \pm 23.2$ & $34.1 \pm 23.7$ & $33.5 \pm 20.1$ & 0.61 & 0.47 & 0.34 & 0.83 \\
\hline \multicolumn{8}{|c|}{ Number of swollen joints } \\
\hline At onset & $8.55 \pm 2.67$ & $7.69 \pm 3.12$ & $8.71 \pm 4.51$ & 0.24 & 0.56 & 0.16 & 0.76 \\
\hline After 12 months & $1.04 \pm 1.68$ & $1.19 \pm 1.62$ & $0.83 \pm 1.19$ & 0.54 & 0.99 & 0.57 & 0.59 \\
\hline \multicolumn{8}{|c|}{ Number of tender joints } \\
\hline At onset & $10.39 \pm 3.33$ & $10.02 \pm 3.32$ & $10.00 \pm 4.82$ & 0.35 & 0.18 & 0.32 & 0.18 \\
\hline After 12 months & $2.65 \pm 2.08$ & $2.33 \pm 2.27$ & $2.65 \pm 2.71$ & 0.71 & 0.71 & 0.49 & 0.93 \\
\hline \multicolumn{8}{|l|}{ VAS } \\
\hline At onset & $8.12 \pm 1.21$ & $7.44 \pm 1.41$ & $7.28 \pm 1.61$ & 0.068 & 0.037 & 0.025 & 0.19 \\
\hline After 12 months & $2.25 \pm 1.41$ & $2.39 \pm 1.57$ & $2.47 \pm 2.10$ & 0.95 & 0.88 & 0.79 & 0.99 \\
\hline \multicolumn{8}{|l|}{ DAS28 } \\
\hline At onset & $5.51 \pm 0.58$ & $5.23 \pm 0.65$ & $5.30 \pm 0.63$ & 0.14 & 0.097 & 0.047 & 0.42 \\
\hline After 12 months & $3.52 \pm 0.89$ & $3.38 \pm 0.92$ & $3.33 \pm 0.74$ & 0.81 & 0.55 & 0.53 & 0.88 \\
\hline \multicolumn{8}{|l|}{ CRP (mg/L) } \\
\hline At onset & $52.50 \pm 42.99$ & $39.30 \pm 36.46$ & $37.55 \pm 33.23$ & 0.34 & 0.17 & 0.14 & 0.52 \\
\hline After 12 months & $14.59 \pm 18.46$ & $8.87 \pm 11.79$ & $17.87 \pm 24.55$ & 0.13 & 0.96 & 0.25 & 0.29 \\
\hline
\end{tabular}

$S D$ standard deviation, $S$ short allele ( $<22$ CAG repeats), $L$ long allele ( $\geq 22$ CAG repeats), ESR erythrocyte sedimentation rate, $V A S$ visual analog scale (0-10), CRP C-reactive protein, DAS28 disease activity score of 28 joints

${ }^{\text {a }}$ Kruskal-Wallis test

b Mann-Whitney test 
Table 2 The improvement of disease activity parameters during treatment with leflunomide in association with $A R$ genotypes

\begin{tabular}{|c|c|c|c|c|c|c|c|}
\hline \multirow[t]{2}{*}{ Parameters } & \multicolumn{3}{|c|}{$A R$ genotypes $($ mean $\pm \mathrm{SD})$} & \multirow[t]{2}{*}{$P$ value $^{\text {a }}$} & \multicolumn{3}{|l|}{$P$ value $^{\mathrm{b}}$} \\
\hline & S-S & S-L & L-L & & S-S vs L-L & S-S vs S-L+L-L & S-S + S-L vs L-L \\
\hline $\operatorname{ESR}(\mathrm{mm} / \mathrm{h})$ & $\begin{array}{l}-23.2 \pm 32.3 \\
(-36.0 \text { to }-10.4)\end{array}$ & $\begin{array}{l}-16.1 \pm 30.0 \\
(-26.3 \text { to }-6.0)\end{array}$ & $\begin{array}{l}-18.0 \pm 23.6 \\
(-28.1 \text { to }-7.8)\end{array}$ & 0.67 & 0.49 & 0.37 & 0.72 \\
\hline $\begin{array}{l}\text { Number of swollen } \\
\text { joints }\end{array}$ & $\begin{array}{l}-7.88 \pm 2.97 \\
(-9.08 \text { to }-6.68)\end{array}$ & $\begin{array}{l}-6.75 \pm 3.29 \\
(-7.86 \text { to }-5.64)\end{array}$ & $\begin{array}{l}-8.30 \pm 4.92 \\
(-10.43 \text { to }-6.18)\end{array}$ & 0.20 & 0.77 & 0.19 & 0.57 \\
\hline $\begin{array}{l}\text { Number of tender } \\
\text { joints }\end{array}$ & $\begin{array}{l}-7.65 \pm 3.21 \\
(-8.95 \text { to }-6.36)\end{array}$ & $\begin{array}{l}-7.64 \pm 3.53 \\
(-8.83 \text { to }-6.44)\end{array}$ & $\begin{array}{l}-7.65 \pm 4.73 \\
(-9.70 \text { to }-5.61)\end{array}$ & 0.81 & 0.64 & 0.88 & 0.53 \\
\hline VAS & $\begin{array}{l}-5.79 \pm 1.86 \\
(-6.54 \text { to }-5.04)\end{array}$ & $\begin{array}{l}-5.10 \pm 1.81 \\
(-5.71 \text { to }-4.48)\end{array}$ & $\begin{array}{l}-4.87 \pm 2.50 \\
(-5.95 \text { to }-3.79)\end{array}$ & 0.12 & 0.091 & 0.044 & 0.26 \\
\hline DAS28 & $\begin{array}{l}-1.99 \pm 0.87 \\
(-2.33 \text { to }-1.65)\end{array}$ & $\begin{array}{l}-1.90 \pm 0.76 \\
(-2.15 \text { to }-1.64)\end{array}$ & $\begin{array}{l}-2.03 \pm 0.86 \\
(-2.40 \text { to }-1.66)\end{array}$ & 0.89 & 0.89 & 0.74 & 0.86 \\
\hline CRP (mg/L) & $\begin{array}{l}-33.12 \pm 40.18 \\
(-49.71 \text { to }-16.54)\end{array}$ & $\begin{array}{l}-33.64 \pm 39.47 \\
(-46.99 \text { to }-20.28)\end{array}$ & $\begin{array}{l}-19.53 \pm 24.14 \\
(-30.23 \text { to }-8.83)\end{array}$ & 0.43 & 0.42 & 0.93 & 0.22 \\
\hline
\end{tabular}

Mean \pm standard deviation (SD) (95\% confidence interval for mean) for the differences of parameters measured after 12 months of therapy and before therapy in each patient

$S$ short allele ( $<22$ CAG repeats), $L$ long allele ( $\geq 22$ CAG repeats), ESR erythrocyte sedimentation rate, VAS visual analog scale, DAS28 disease activity score of 28 joints, CRP C-reactive protein

${ }^{a}$ Kruskal-Wallis test

${ }^{\mathrm{b}}$ Mann-Whitney test

\section{Discussion}

This is the first study examining the association between CAG repeat polymorphism in the $A R$ gene and response to therapy in women with RA treated with LEF. Response to treatment was evaluated on the basis of improvement of disease activity parameters, such as DAS28, VAS, number of swollen and tender joints, ESR, and CRP levels. The analysis found no statistically significant associations. Previous studies have shown the inverse correlation of $\mathrm{CAG}$ length with transcriptional activity of the $A R$, which may be associated with altered response to androgens [16, 17]. Androgen serum concentrations were not measured in our patients, and their associations with CAG length and response to therapy could not be analyzed.

So far, the length of the CAG repeat polymorphism of $A R$ in RA has not been widely investigated. Studies regarding this polymorphism suggest associations between CAG repeat length and clinical features of RA but no association with susceptibility to RA [24-26]. Only one study examined the association between CAG polymorphism of the $A R$ gene and response to therapy in RA. Patients harboring long CAG alleles with $>23$ repeats had an increased risk of a worse response to DMARDs, but it was not shown how many patients were treated with LEF [27].

The implication for our study was the observation that sex hormones play an important role in RA pathogenesis and that response to DMARDs is poorer in women than in men [12-14]. Moreover, in our previous study, we indicated better response to treatment in patients with ESR1 rs9340799 AA and rs2234693 TT genotypes after 12 months of therapy with LEF [19]. Additionally, the influence of sex hormones on LEF action has been confirmed by in vitro studies. Cutolo et al. [28] studied the combined effects of LEF, $17 \beta$-estradiol, and testosterone on inflammatory cytokine production by cultured macrophages obtained from activated human monocytes. The authors evaluated the levels of interleukin 6 (IL-6), tumor necrosis factor alpha (TNF- $\alpha$ ), and transforming growth factor beta (TGF- $\beta$ ) in cell cultures. They showed that LEF significantly down-regulated cytokine production. Treatment with testosterone induced a significant decrease in cytokine production in differentiated macrophages, whereas $17 \beta$-estradiol increased cytokine expression. Interestingly, in a synergistic way, LEF in combination with testosterone induced a further significant decrease in all cytokines analyzed versus cells already treated with testosterone alone. On the other hand, $17 \beta$-estradiol inhibited the decrease of LEF-induced cytokine production in differentiated macrophages. The authors conclude that $17 \beta$-estradiol seems to contrast, but testosterone seems to synergize, LEF activity, and these results might support the observations that a less effective therapeutic effect in women with RA is due to the action of estrogens [28]. Montagna et al. [29] evaluated the proapoptotic activity of LEF in combination with sex hormones on cultures of human macrophages treated with LEF alone or in the presence of $17 \beta$-estradiol or testosterone. The authors showed that LEF significantly increased the expression of 
Table 3 Disease activity parameters and their changes during 12 months of treatment with leflunomide in patients stratified according to median CAG repeat length of shorter androgen receptor $(A R)$ allele, longer $A R$ allele, and their mean

\begin{tabular}{|c|c|c|c|c|c|c|c|c|c|}
\hline \multirow[t]{3}{*}{ Parameters } & \multicolumn{3}{|c|}{ CAG repeats in shorter allele } & \multicolumn{3}{|c|}{ CAG repeats in longer allele } & \multicolumn{3}{|c|}{$\begin{array}{l}\text { Mean of CAG repeats in shorter and longer } \\
\text { alleles }^{\text {b }}\end{array}$} \\
\hline & \multicolumn{3}{|c|}{ Mean values \pm SD } & \multicolumn{3}{|c|}{ Mean values \pm SD } & \multicolumn{3}{|c|}{ Mean values \pm SD } \\
\hline & $\leq 19 \mathrm{CAG}$ & $>19 \mathrm{CAG}$ & $p^{\mathrm{a}}$ & $\leq 23 \mathrm{CAG}$ & $>23 \mathrm{CAG}$ & $p^{\mathrm{a}}$ & $\leq 21.5 \mathrm{CAG}$ & $>21.5 \mathrm{CAG}$ & $p^{\mathrm{a}}$ \\
\hline \multicolumn{10}{|l|}{$\operatorname{ESR}(\mathrm{mm} / \mathrm{h})$} \\
\hline At onset & $53.5 \pm 27.3$ & $51.4 \pm 25.8$ & 0.71 & $57.2 \pm 27.7$ & $47.2 \pm 24.2$ & 0.044 & $56.3 \pm 28.4$ & $48.8 \pm 24.1$ & 0.17 \\
\hline After 12 months & $39.1 \pm 25.5$ & $32.7 \pm 19.8$ & 0.36 & $34.8 \pm 20.6$ & $36.3 \pm 25.0$ & 0.90 & $35.5 \pm 21.4$ & $35.5 \pm 23.7$ & 0.96 \\
\hline Change & $-16.9 \pm 32.8$ & $-20.3 \pm 26.2$ & 0.69 & $-23.5 \pm 30.2$ & $-12.6 \pm 26.6$ & 0.099 & $-23.1 \pm 31.2$ & $-14.8 \pm 26.6$ & 0.23 \\
\hline \multicolumn{10}{|c|}{ Number of swollen joints } \\
\hline At onset & $8.27 \pm 3.35$ & $8.15 \pm 3.55$ & 0.61 & $8.17 \pm 3.20$ & $8.23 \pm 3.72$ & 0.79 & $8.19 \pm 3.29$ & $8.21 \pm 3.62$ & 0.91 \\
\hline After 12 months & $1.24 \pm 1.89$ & $0.90 \pm 1.17$ & 0.72 & $1.29 \pm 1.83$ & $0.73 \pm 0.93$ & 0.41 & $1.17 \pm 1.87$ & $0.93 \pm 1.13$ & 0.86 \\
\hline Change & $-7.59 \pm 3.57$ & $-7.46 \pm 3.89$ & 0.75 & $-7.23 \pm 3.37$ & $-7.89 \pm 4.18$ & 0.51 & $-7.54 \pm 3.47$ & $-7.50 \pm 4.00$ & 0.87 \\
\hline \multicolumn{10}{|c|}{ Number of tender joints } \\
\hline At onset & $10.04 \pm 3.31$ & $10.17 \pm 4.09$ & 0.80 & $10.34 \pm 3.59$ & $9.88 \pm 3.94$ & 0.30 & $10.57 \pm 3.65$ & $9.72 \pm 3.84$ & 0.097 \\
\hline After 12 months & $2.73 \pm 2.18$ & $2.35 \pm 2.43$ & 0.25 & $2.65 \pm 2.15$ & $2.35 \pm 2.54$ & 0.30 & $2.59 \pm 2.26$ & $2.45 \pm 2.40$ & 0.70 \\
\hline Change & $-7.73 \pm 3.63$ & $-7.58 \pm 3.89$ & 0.78 & $-7.56 \pm 3.45$ & $-7.76 \pm 4.17$ & 0.82 & $-7.95 \pm 3.56$ & $-7.36 \pm 3.95$ & 0.39 \\
\hline \multicolumn{10}{|l|}{ VAS } \\
\hline At the onset & $7.60 \pm 1.28$ & $7.57 \pm 1.57$ & 1.00 & $7.99 \pm 1.30$ & $7.17 \pm 1.48$ & 0.0025 & $7.97 \pm 1.28$ & $7.25 \pm 1.51$ & 0.010 \\
\hline After 12 months & $2.34 \pm 1.63$ & $2.39 \pm 1.72$ & 0.79 & $2.49 \pm 1.51$ & $2.22 \pm 1.87$ & 0.23 & $2.38 \pm 1.56$ & $2.36 \pm 1.78$ & 0.92 \\
\hline Change & $-5.36 \pm 1.94$ & $-5.16 \pm 2.13$ & 0.58 & $-5.45 \pm 1.77$ & $-4.99 \pm 2.35$ & 0.35 & $-5.57 \pm 1.76$ & $-4.95 \pm 2.25$ & 0.16 \\
\hline \multicolumn{10}{|l|}{ DAS28 } \\
\hline At the onset & $5.34 \pm 0.61$ & $5.31 \pm 0.66$ & 0.77 & $5.42 \pm 0.64$ & $5.23 \pm 0.62$ & 0.057 & $5.42 \pm 0.65$ & $5.25 \pm 0.61$ & 0.074 \\
\hline After 12 months & $3.56 \pm 0.89$ & $3.30 \pm 0.83$ & 0.39 & $3.51 \pm 0.91$ & $3.27 \pm 0.77$ & 0.33 & $3.47 \pm 0.95$ & $3.35 \pm 0.76$ & 0.79 \\
\hline Change & $-1.89 \pm 0.83$ & $-2.02 \pm 0.81$ & 0.74 & $-1.91 \pm 0.80$ & $-2.04 \pm 0.83$ & 0.55 & $-1.98 \pm 0.82$ & $-1.95 \pm 0.81$ & 0.71 \\
\hline \multicolumn{10}{|l|}{$\mathrm{CRP}(\mathrm{mg} / \mathrm{L})$} \\
\hline At the onset & $43.50 \pm 41.16$ & $41.59 \pm 35.20$ & 0.66 & $50.85 \pm 43.06$ & $33.67 \pm 29.12$ & 0.049 & $50.44 \pm 44.95$ & $35.44 \pm 28.65$ & 0.23 \\
\hline After 12 months & $15.00 \pm 18.36$ & $11.42 \pm 17.96$ & 0.38 & $13.33 \pm 16.70$ & $12.53 \pm 19.95$ & 0.47 & $12.90 \pm 16.47$ & $13.05 \pm 19.71$ & 0.70 \\
\hline Change & $-29.69 \pm 40.67$ & $-29.78 \pm 33.22$ & 0.30 & $-36.04 \pm 43.48$ & $-21.91 \pm 23.26$ & 0.48 & $-36.76 \pm 45.45$ & $-23.22 \pm 24.05$ & 0.74 \\
\hline
\end{tabular}

$S D$ standard deviation, $E S R$ erythrocyte sedimentation rate, $V A S$ visual analog scale, $D A S 28$ disease activity score of 28 joints, $C R P C$-reactive protein,

${ }^{\text {a }}$ Mann-Whitney test

${ }^{\mathrm{b}}$ (shorter allele CAG repeats + longer allele CAG repeats)/2

Table 4 Spearman rank correlation coefficients and their $95 \%$ confidence intervals $(\mathrm{CI})$ between improvement of rheumatoid arthritis disease activity parameters during treatment with leflunomide and CAG repeat length of androgen receptor $(A R)$ alleles (shorter, longer, and mean)

No significant $(p<0.05)$

correlations were found

ESR erythrocyte sedimentation rate, $V A S$ visual analog scale, $D A S 28$ disease activity score of 28 joints, $C R P$ C-reactive protein

${ }^{a}$ (shorter allele CAG repeats + longer allele CAG repeats)/2

\begin{tabular}{llll}
\hline Parameters & $\begin{array}{l}\text { CAG repeats in } \\
\text { shorter allele }\end{array}$ & $\begin{array}{l}\text { CAG repeats in } \\
\text { longer allele }\end{array}$ & $\begin{array}{l}\text { Mean of CAG repeats in } \\
\text { shorter and longer alleles }\end{array}$ \\
\hline ESR & +0.06 & +0.11 & +0.09 \\
Number of swollen joints & $(-0.16-+0.28)$ & $(-0.11-+0.32)$ & $(-0.13-+0.30)$ \\
& -0.07 & +0.05 & +0.01 \\
Number of tender joints & $(-0.28-+0.15)$ & $(-0.17-+0.27)$ & $(-0.21-+0.23)$ \\
& +0.03 & +0.04 & +0.04 \\
VAS & $(-0.19-+0.25)$ & $(-0.18-+0.26)$ & $(-0.18-+0.25)$ \\
& +0.13 & +0.15 & +0.17 \\
DAS28 & $(-0.09-+0.34)$ & $(-0.07-+0.36)$ & $(-0.05-+0.37)$ \\
& -0.01 & +0.02 & +0.003 \\
CRP & $(-0.22-+0.21)$ & $(-0.20-+0.23)$ & $(-0.22-+0.22)$ \\
& +0.02 & +0.03 & +0.01 \\
& $(-0.20-+0.24)$ & $(-0.20-+0.25)$ & $(-0.21-+0.23)$ \\
\hline
\end{tabular}


apoptotic proteins. On the contrary, $17 \beta$-estradiol significantly decreased the proapoptotic activity of LEF and testosterone significantly increased apoptotic proteins in all conditions [29].

Androgens exert anti-inflammatory activities in synovial tissue, which contrasts with the proinflammatory activities exerted by estrogens [30]. Serum testosterone levels are inversely correlated with RA disease activity, and dehydroepiandrosterone sulfate (DHEAS) levels are inversely correlated with both disease duration and clinical severity [31]. Adrenal and gonadal androgens, which exert antiinflammatory activities, are significantly decreased in inflamed tissues during active RA in both male and female patients $[30,32]$. Interestingly, increased aromatization of androgens to estrogens has been demonstrated in cultured synovial cells from RA patients [32, 33]. When androgens are converted to their corresponding estrogens, the effects are mediated by estrogen receptors. Our previous study indicated an association between the response of women with RA to LEF and ESR1 gene polymorphisms. Results presented in the study reported here suggest no correlation between CAG repeat polymorphism in the androgen receptor gene and response to LEF treatment of women with RA. This lack of association may be due to increased conversion of androgens to estrogens in RA, which exert proinflammatory activities by estrogen receptors. Nevertheless, the role of androgens, androgen receptors, and CAG repeat polymorphism in the $A R$ gene in the response to RA therapy requires further investigations.

Open Access This article is distributed under the terms of the Creative Commons Attribution Noncommercial License which permits any noncommercial use, distribution, and reproduction in any medium, provided the original author(s) and source are credited.

\section{References}

1. Wollheim FA (2001) Approaches to rheumatoid arthritis in 2000. Curr Opin Rheumatol 13(3):193-201

2. Schipper LG, Fransen J, Barrera P, den Broeder AA, Van Riel PL (2009) Methotrexate therapy in rheumatoid arthritis after failure to sulphasalazine: to switch or to add? Rheumatology 48(10):12471253

3. Smolen JS, Aletaha D, Koeller M, Weisman MH, Emery P (2007) New therapies for treatment of rheumatoid arthritis. Lancet 370 (9602):1861-1874

4. Herrmann ML, Schleyerbach R, Kirschbaum BJ (2000) Leflunomide: an immunomodulatory drug for the treatment of rheumatoid arthritis and other autoimmune diseases. Immunopharmacology 47(2-3):273-289

5. Pawlik A, Herczynska M, Kurzawski M, Safranow K, Dziedziejko V, Drozdzik M (2009) The effect of exon (19 C>A) dihydroorotate dehydrogenase gene polymorphism on rheumatoid arthritis treatment with leflunomide. Pharmacogenomics 10(2):303-309
6. Grabar PB, Rozman B, Logar D, Praprotnik S, Dolzan V (2009) Dihydroorotate dehydrogenase polymorphism influences the toxicity of leflunomide treatment in patients with rheumatoid arthritis. Ann Rheum Dis 68(8):1367-1368

7. Miceli-Richard C, Dougados M (2003) Leflunomide for the treatment of rheumatoid arthritis. Expert Opin Pharmacother 4 (6):987-997

8. Dayer J-M, Cutolo M (2005) Is there a rational to using leflunomide in early rheumatoid arthritis? Clin Exp Rheumatol 23(3):404-412

9. Kellner H, Bornholdt K, Hein G (2010) Leflunomide in the treatment of patients with early rheumatoid arthritis-results of a prospective non-interventional study. Clin Rheumatol 29(8):913-920

10. Litinsky I, Paran D, Levartovsky D, Wigler I, Kaufman I, Yaron I, Yaron M, Caspi D, Elkayam O (2006) The effects of leflunomide on clinical parameters and serum levels of IL-6, IL-10, MMP-1 and MMP-3 in patients with resistant rheumatoid arthritis. Cytokine 33(2):106-110

11. Cutolo M, Sulli A, Ghiorzo P, Pizzorni C, Craviotto C, Villaggio B (2003) Anti-inflammatory effects of leflunomide on cultured synovial macrophages from patients with rheumatoid arthritis. Ann Rheum Dis 62(4):297-302

12. Kvien TK, Uhlig T, Ødegård S, Heiberg MS (2006) Epidemiological aspects of rheumatoid arthritis: the sex ratio. Ann N Y Acad Sci 1069:212-222

13. Sokka T, Toloza S, Cutolo M et al (2009) Women, men, and rheumatoid arthritis: analyses of disease activity, disease characteristics, and treatments in the QUEST-RA study. Arthritis Res Ther 11(1):R7

14. Cutolo M, Capellino S, Montagna P, Villaggio B, Sulli A, Seriolo B, Straub RH (2003) New roles for estrogens in rheumatoid arthritis. Clin Exp Rheumatol 21(6):687-690

15. Giwercman YL, Xu C, Arver S, Pousette A, Reneland R (1998) No association between the androgen receptor gene CAG repeat and impaired sperm production in Swedish men. Clin Genet 54 (5):435-436

16. Zitzmann M, Nieschlag E (2003) The CAG repeat polymorphism within the androgen receptor gene and maleness. Int J Androl 26 (2):76-83

17. Chamberlain NL, Driver ED, Miesfeld RL (1994) The length and location of CAG trinucleotide repeats in the androgen receptor Nterminal domain affect transactivation function. Nucleic Acids Res 22(15):3181-3186

18. Nelson KA, Witte JS (2002) Androgen receptor CAG repeats and prostate cancer. Am J Epidemiol 155(10):883-890

19. Dziedziejko V, Kurzawski M, Safranow K, Chlubek D, Pawlik A (2011) The effect of ESR1 and ESR2 gene polymorphisms on the outcome of rheumatoid arthritis treatment with leflunomide. Pharmacogenomics 12(1):41-47

20. Felson DT, Anderson JJ, Boers M et al (1995) American College of Rheumatology, Preliminary definition of improvement in rheumatoid arthritis. Arthritis Rheum 38(6):727-735

21. Fuchs HA, Brooks RH, Callahan LF, Pincus T (1989) A simplified twenty-eight-joint quantitative articular index in rheumatoid arthritis. Arthritis Rheum 32(5):531-537

22. Prevoo ML, van' t Hof MA, Kuper HH, van Leeuwen MA, van de Putte LB, van Riel PL (1995) Modified disease activity scores that include twenty-eight-joint counts. Development and validation in a prospective longitudinal study of patients with rheumatoid arthritis. Arthritis Rheum 38(1):44-48

23. Latil AG, Azzouzi R, Cancel GS, Guillaume EC, Cochan-Priollet B, Berthon PL, Cussenot O (2001) Prostate carcinoma risk and allelic variants of genes involved in androgen biosynthesis and metabolism pathways. Cancer 92(5):1130-1137

24. Kawasaki T, Ushiyama T, Ueyama H, Inoue K, Mori K, Ohkubo I, Hukuda S (1999) Polymorphic CAG repeats of the androgen 
receptor gene and rheumatoid arthritis. Ann Rheum Dis 58 (8):500-502

25. Lo SF, Huang CM, Tsai CH, Chen WC, Lai CC, Tsai Y, Tsai FJ (2006) Androgen receptor gene polymorphism and rheumatoid arthritis in Taiwan. Clin Exp Rheumatol 24(2):209-210

26. Karlson EW, Chibnik LB, McGrath M, Chang SC, Keenan BT, Costenbader KH, Fraser PA, Tworoger S, Hankinson SE, Lee IM, Buring J, De Vivo I (2009) A prospective study of androgen levels, hormone-related genes and risk of rheumatoid arthritis. Arthritis Res Ther 11(3):R97

27. Yu SF, Cheng TT, Hsu YH, Lai HM, Chen YC, Chiu CK, Lin KM, Chang C, Chen CJ, Kang HY (2007) Association of trinucleotide (CAG and GGC) repeat polymorphism of androgen receptor gene in Taiwanese women with refractory or remission rheumatoid arthritis. Clin Rheumatol 26(12):2051-2058

28. Cutolo M, Montagna P, Brizzolara R, Sulli A, Seriolo B, Villaggio B, Triolo P, Clerico P, Soldano S (2009) Sex hormones modulate the effects of Leflunomide on cytokine production by cultures of differentiated monocyte/macrophages and synovial macrophages from rheumatoid arthritis patients. J Autoimmun 32(3-4):254-260

29. Montagna P, Brizzolara R, Soldano S, Pizzorni C, Sulli A, Cutolo M (2009) Sex hormones and leflunomide treatment of human macrophage cultures: effects on apoptosis. Int J Clin Exp Med 2(3):221-232

30. Cutolo M (2009) Androgens in rheumatoid arthritis: when are they effectors? Arthritis Res Ther 11(5):126

31. Gordon D, Beastall GH, Thomson JA, Sturrock RD (1988) Prolonged hypogonadism in male patients with rheumatoid arthritis during flares in disease activity. Br J Rheumatol 27 (6):440-444

32. Castagnetta LA, Carruba G, Granata OM, Stefano R, Miele M, Schmidt M, Cutolo M, Straub RH (2003) Increased estrogen formation and estrogen to androgen ratio in the synovial fluid of patients with rheumatoid arthritis. J Rheumatol 30(12):2597-2605

33. Schmidt M, Naumann H, Weidler C, Schellenberg M, Anders S, Straub RH (2006) Inflammation and sex hormone metabolism. Ann N Y Acad Sci 1069:236-246 